\title{
Is Taiwan a Presidential System?
}

\section{Ondrej Kucera}

\section{OpenEdition}

\section{Journals}

Édition électronique

URL : http://journals.openedition.org/chinaperspectives/1036

DOI : 10.4000/chinaperspectives.1036

ISSN : 1996-4617

\section{Éditeur}

Centre d'étude français sur la Chine contemporaine

\section{Édition imprimée}

Date de publication : 1 juillet 2006

ISSN : 2070-3449

\section{Référence électronique}

Ondrej Kucera, "Is Taiwan a Presidential System? », China Perspectives [En ligne], 66 | July- August 2006, mis en ligne le 01 août 2009, consulté le 28 octobre 2019. URL : http://journals.openedition.org/ chinaperspectives/1036; DOI : 10.4000/chinaperspectives.1036

Ce document a été généré automatiquement le 28 octobre 2019

(c) All rights reserved 


\title{
Is Taiwan a Presidential System?
}

\author{
Ondrej Kucera
}

1 The Taiwanese government underwent substantial change in the 1990s. A majority of political scientists and some politicians classify or claim its system to now be semipresidential $^{2}$. However there are some competing interpretations that claim it to be either "of a parliamentarian kind"3, "being presidential" or "moving towards a

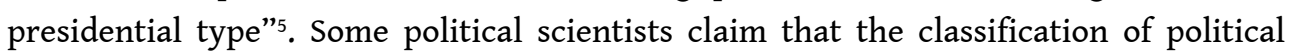
systems is not trichotomic (parliamentarian, semi-presidential, presidential) but only dichotomic, and in such a case Taiwan also has to be classified or interpreted as either a presidential or parliamentarian system ${ }^{6}$. Maurice Duverger, the father of the concept of a semi-presidential government, asserts that a semi-presidential system is not a synthesis of a presidential system and a parliamentary system, but rather a system which-depending on whether the President has majority support in the legislaturereverts either to a parliamentary or to a presidential form of government ${ }^{7}$.

2 We will try to answer three questions in this article: Is it always possible to "classify" given government as one particular type or another, or is it sufficient to "interpret ${ }^{9}$ the nature" of that government? How could the government of Taiwan be classified? What, if any, are the consequences of such classification?

Presidential and parliamentary systems

Robert Elgie was the first to argue that there are three methods for classification of semi-presidential systems in the literature: "The first type of definition is one that considers only the actual powers of political actors, or, to put it another way, the relational properties of democratic regime types... The second type of definition is one that combines formal constitutional arrangements with actual powers, or, more accurately, dispositional and relational properties... .... third type of definition derived from the dispositional properties of regime types alone" ${ }^{10}$ [this definition is thus based only on the analysis of formal constitutional arrangements].

4 The combination of dispositional and relational properties is used in the definition of Maurice Duverger: "The concept of semi-presidential form of government....is defined ...by the content of Constitution. A political regime is considered as semi-presidential if the Constitution which established it combines three elements: (1) the President of the 
Republic is elected by universal suffrage; (2) he possesses quite considerable powers; (3) he has opposite him, however, a Prime Minister and ministers who possess executive and governmental power and can stay in office only if the Parliament does not show opposition to them..."11.

5 This definition was considerably modified by Giovanni Sartori ${ }^{12}$. Sartori puts the emphasis of this definition on the power relationship between President and Prime Minister (four of the five criteria), but it still focuses on the Constitution. Patrick O'Neil defines a semi-presidential regime as one where the executive power is divided between the President and the Prime Minister, but where the President has quite substantial powers ${ }^{13}$. From this type of definition we have to class the respective governments by looking at the respective powers of the head of state and head of government. The direct election of the President is irrelevant for this definition ${ }^{14}$. This definition is concerned only with the real power characteristics of the respective system (also referred to as relational properties).

6 Robert Elgie in his general work on the classification of regime types ${ }^{15}$ and also in a work focusing specifically on semi-presidential regimes ${ }^{16}$ affirms that "classifications of regime types should be derived either from the dispositional properties of regimes or from their relational properties but not from both together" ${ }^{17}$. He also claims that "it is better to classify regime types on the basis of their dispositional properties rather than their relational properties because they can be objectively derived from the Constitution, and therefore create conditions for a more scientific analysis..." ${ }^{18}$. His proposed definition of semi-presidential regime based only on dispositional properties of the regime has only three criteria: a popularly elected President; a fixed term for the President; the President exists alongside the Prime Minister and a cabinet responsible to Parliament ${ }^{19}$.

Constitutional regimes and political systems

7 The Constitution can only have "potential" relational properties, which are actually implemented (in various different ways and to different degrees) into the political system. In his discussion of relational properties, Elgie, as other authors, mix the potential relational properties and their actual realisation. They mix the power positions of players prescribed by the Constitution and the actual power positions in the system.

8 The French constitutional scientist Olivier Duhamel emphasises the need to distinguish the definition criteria based on constitutional structure and the ones based on the behaviour of government (and its key players). He considers the first set of criteria to define the constitutional regime of the particular country and the second set of criteria to define the particular country's political system ${ }^{20}$. We agree with the above-stated methodological position, a variation of which has recently been articulated by Thomas Sedelius: "It seems more appropriate to argue ...that semi-presidential systems exhibit various forms of political practices within the same constitutional framework" ${ }^{21}$.

9 It is strictly necessary to distinguish between the analysis of a constitutional regime and a political system. Two theories can be used for describing characteristics of political systems: Arend Lijphart's theory of consensual government and Guillermo O'Donnel's theory of delegative democracy. Lijphart defines political systems on the continuum from majoritarian to consensual ${ }^{22}$. The majoritarian political system corresponds more with the presidential regime, or as Thomas Poguntke puts it - "majoritarian democracies have a higher potential for presidential tendencies..." ${ }^{23}$. 

functioning of South American presidential democracies ${ }^{24}$, deals with the real behaviour of a President in a presidential system of government, and it defines one side of another typological continuum, which is the delegative democracy in opposition to "classical" representative democracy.

11 We divide the definition of the Taiwanese system of government into the definition of its constitutional regime and into the characterisation of its political system. Only the constitutional regime can be defined and therefore the trichotomic classification of regimes is applicable only to the first part of the definition. The political system can be merely described or characterised, and therefore only the tendencies towards presidentialisation of a respective non-presidential constitutional regime (parliamentary, semi-presidential) can be observed.

Taiwanese constitutional regime

The President is directly (popularly) elected according to the Article 2, paragraph 1 of Additional articles to the Constitution of the Republic of China (AA). He is, according to Article 2, paragraph 6 of AA, elected for a fixed term of four years. Article 3, paragraph 1 of AA creates the Prime Minister (president of Executive Yuan) and cabinet (Executive Yuan). Both are responsible to Parliament (Legislative Yuan) according to Article 3, paragraph 2. The Legislative Yuan has the specific right to vote on a call of no confidence, which would remove the Prime Minister and cabinet. All the dispositional properties of the definition of semi-presidential constitutional regime are therefore met.

The President has only one power that he can exercise on his own: the power to appoint and remove Prime Ministers. The rest of the important President's decisions are either countersigned by the Prime Minister or the Legislative Yuan. It therefore necessitates the player's co-operation ${ }^{25}$. The President has, according to the Article 2, paragraph 3 of AA, the power "to issue emergency decrees and take all the necessary measures to avert imminent danger affecting the security of the state or of the people or to cope with any serious financial or economic crisis" ${ }^{26}$. He therefore has potential extraordinary powers. "In case of disputes between two or more Yuan other than those concerning which there are relevant provisions in this Constitution, the President may call a meeting of the presidents of the Yuan concerned for consultation with a view to reaching a solution" ${ }^{27}$. Again the Constitution prescribes him the power to initiate arbitration between the key players. The possibility of recall of the elected official ${ }^{28}$ and the exercise of the right of referendum ${ }^{29}$ are features of direct democracy prescribed by the Constitution that exist in the political reality of today's Taiwan. The Constitution, however, also stipulates in Article 136 that the people have the right of initiative, but this has in no way affected the political reality, nor is there even a mechanism to exercise this right. It appears that the relational properties present in the Republic of China Constitution also prescribe for Taiwan a semi-presidential constitutional regime.

Majoritarian government on Taiwan

14

The KMT government was, until the 2000 presidential elections, clearly a one-party cabinet as a result of the KMT legislative majority, and also concurrently holding the presidency. Shelley Rigger predicted in 2000 that the Democratic Progressive Party (DPP)'s Chen Shui-bian's victory would force him to form a coalition government that would have to include members of KMT as well as independent ${ }^{30}$. The prediction proved to be true concerning the new Executive Yuan's composition, however this 
cross-party membership wasn't the result of coalition agreement, but members of the opposition parties (mainly KMT) entered the government on an individual basis. The situation was considered by President Chen to be temporary and he personally vowed to create a genuine coalition with the opposition parties after the 2001 Parliamentary elections ${ }^{31}$. However the Cabinet created after the parliamentary elections in 2001 was again composed mainly of politicians loyal to President. The new Prime Minister Yu Shyi-kun has been a long-time co-worker with the President, having been a secretary to the Presidential office, so the Cabinet has become more of a President's secretariat and the number of DPP party members increased.

After the parliamentary elections of 2004, with the appointment of the Chen's longstanding DPP rival Frank Hsieh to the position of Prime Minister, the number of DPP members has increased again ${ }^{32}$ and the Cabinet has become a more independent body. The attempts to include some opposition KMT politicians in the Cabinet on an official basis (specifically the offer of the vice-premier position to the KMT) have been blocked by the conditions the KMT put forward. These conditions could have signalled a push towards a two-party coalition Cabinet, but were rejected by the DPP. Never during his time in office has President Chen made a concrete offer or has entered into formal consultations to create a coalition-government ${ }^{33}$. There were rumours in December 2005 in Taiwan that Chen was talking again about creating a coalition government, ${ }^{34}$ but none of them proved to be true.

Until 2000 the system was clearly dominated by executive power. It was a logical outgrowth of the situation where the presidency and the ruling party chairmanship were dominated by one person (as in the case of the Chiangs and Lee Teng-hui). The situation was changed by the 2000 presidential elections and Parliament has acquired a more important role. The executive branch has retained the agenda-setting power, but Parliament has begun to learn how to be a veto player (especially after Ma Ying-jeou's accession to the KMT party chairmanship).

Chen Shui-bian acquired the chairmanship of the DPP in his move to retain domination of executive power (emulating the previous KMT situation), and the party has become a platform for communication of the President's executive policies (he stepped down after losing the 2004 parliamentary elections). However the inability of the President to overpower the legislature and to implement his issues through legislation has resulted in legislative "gridlock". "The Law Governing Legislator's Exercise of Power" enacted on January 25th 1999 and revised on January 25th $2002^{35}$ could alleviate the gridlock. This law has provided for the possibility of partisan negotiations in the legislature, when consensus over a Bill cannot be reached. However, this method is criticised because it lacks transparency of decision ${ }^{36}$. On the other hand the Legislative Yuan is asserting its will by its ability to cut the government's budget, thus strengthening its own position ${ }^{37}$.

Wu Shan-yu argues that after his initial uncertainty, Chen Shui-bian has slowly learned how to assert himself over the Legislative Yuan and he is gradually moving towards being the dominant one in the relationship ${ }^{38}$. He was seen to be a reactive President in the first year of his presidency ${ }^{39}$, but later demonstrated his ability to influence policymaking even without a legislative majority. He skilfully uses direct appeals to the public, thus setting a precedent for future Presidents to emulate ${ }^{40}$. The best example of a policy victory can be seen in Chen's proposal for referendum legislation. Due to public pressure, Parliament has supported a watered down version of a referendum, allowing 
Chen to score a policy victory ${ }^{41}$. Chen is trying hard to maximise his powers by emulating his KMT predecessors. The condition of the domination of executive power is therefore met, even with an apparent tendency towards losing this dominance, especially in 2005 (when opposition leaders made trips to the mainland), while opposition uses its tools and learns how to be effective.

The effective number of political parties on $\operatorname{Taiwan}^{42}(1995-2.54 ; 1998-2.46)$ has shot up at the 2001 parliamentary elections (3.45) and declined a bit in the elections of 2004 (3.26). The emergence of pan-blue and pan-green camps in the 2001 election has kept the Taiwanese party system close to real bipartism. The recent constitutional change ${ }^{43}$ will probably lead the party system towards bipartism by its own inertia, as is already happening by the transfer of MPs from the PFP to the KMT.

There is very strong network of independent local factions on Taiwan, held together by ties of blood, kinship, marriage and personal relationships ${ }^{44}$. This system therefore strongly deters the creation of the centralist, government-created system of interest groups. It was estimated in 2000 that about $60 \%$ of legislators represented local factions ${ }^{45}$. The thesis that Taiwan enjoys a plurality of interest groups is also supported by Ya-Chung Chuang, who claims that on Taiwan, there has gradually emerged a network of grassroots social movements ${ }^{46}$, and by Ming-sho Ho who claims that "the DPP government opened new policy channels. Social movement activists were given the chance to work within existing government institutions, [and] once they secured government positions, these activists were able to produce some procedural changes as favored by social movements" 47 .

The Taiwanese political system can be characterised by strong majoritarian tendencies, which reflect Taiwan's authoritarian past, and these were sustained after the beginning of democratisation due to the prevailing presidential government during Lee's era, even while already having established a semi-presidential constitutional regime. The type of democratisation on Taiwan - the ruling elite engineered type, which retained the elite in power long after successful regime transition-has therefore retained part of the previous authoritarian regime's political culture-the majoritarian behaviour. These tendencies were only mildly moderated after the 2000 presidential elections by Taiwan's constitutional regime and voting system.

Delegative democracy on Taiwan

Delegative democracy influences the functioning of the government, and especially the move towards personalised (presidentialised) government, while having a semipresidential constitutional regime can be viewed as less behaving the way prescribed by the Constitution and so less representing the election results.

Before the 2000 government split, it was not really necessary for the Presidents to assert themselves as "supra party" because they commanded a clear majority. President Chen, lacking this majority, claimed in his first inaugural speech, in 2000, that he would attempt "to establish a supra-party government"... On coming to office he called for the creation of "a government for all the people". He also called for the creation of a "cross-party alliance for national stability" during the legislative election of $2001^{48}$. His tactics of directly appealing to the public ${ }^{49}$ can also be viewed as trying to circumvent the prescribed constitutional method of governing. major stumbling block hindering reform initiatives through tardiness in dealing with 
government bills ${ }^{50}$. Hermann Halbeisen also argues that Chen's supra-party approach... "has to be seen as a conscious attempt to split the political opposition, thereby eliciting hostile reactions of both the KMT and the PFP".

The President has been traditionally the keystone of politics for the reasons of concurrent chairmanship of the previously predominant party-the KMT. After the constitutional revision of the appointment of the Prime Minister (it no longer requires the consent of the Legislative Yuan), in popular understanding the President of the Republic became Taiwan's chief executive. Premier Lien Chan once described himself as "the secretary of the President" ${ }^{51}$. Yu Shyi-kun-former chief of staff of the presidential office behaved as the "chief of staff" even as Prime Minister.

Revising the DPP party charter and making the incumbent President automatically the chairman of the DPP has also strengthened the position of the President in the political process. However this characteristic has changed since the 2004 parliamentary elections. President Chen stepped down from his position of party chairman, and the DPP party situation now appears to be reverting more to the consensual politics of three key players (President, Prime Minister, party chairman) and is becoming more representative.

The tradition of isolating himself from existing political institutions and the tradition of circumventing them had already begun with Lee Teng-hui at the beginning of his presidency due to Lee's lack of support in existing political institutions, even in his own party. The first successful circumventing action was Lee's call for a National Affairs Conference of leaders across the political spectrum, which was used to break the "gridlock" within the KMT over political reform ${ }^{52}$. Another instance of such behaviour was the convention of the National Development Council, which was held in December 1996 with participants from the government and the public sector. The Council reached consensus on constitutional reform which is currently being implemented (as of $2005)^{53}$. By both these extra-governmental bodies Lee created extra-constitutional institutions used for promoting his personal policies. In his second term of office in particular Lee's strong leadership became more arbitrary and resulted in massive corruption and a confrontational style which helped to fracture the KMT ${ }^{54}$, including pushing aside his designated successor, former Taiwan governor James Soong, and personally promoting his own premier, Lien Chan. The KMT would not have nominated him had it not been for Lee's personal push ${ }^{55}$. He thus created by his behaviour a negative institutional legacy undercutting the new presidency under $\mathrm{Chen}^{56}$.

In the beginning of his first term Chen surrounded himself with about thirty aides known as "Boy scouts", and with them tried rather unsuccessfully to set his own agenda. In the first year of his presidency he isolated himself even within his own party ${ }^{57}$. The convening of the National Economic Development Advisory Conference (first proposed in a televised speech on May 18th 2001) provided a vehicle for Chen to push his own policies and, as Halbeisen claims, "it was the first time Chen had shown that he had both understood his position of weakness and also how, with that position, to still get what he wanted"58.

29 Taiwan exhibits a clear drift toward the situation where the real decision-making power in the system is "delegated" to the President. It is also conforming to Poguntke's definition of presidentialisation of governments.

Aftermath of the 2004 parliamentary elections 
Shui-bian apologised to DPP supporters right after the elections (in which, shortly after narrowly winning re-election under dubious conditions, he did not achieve a parliamentary majority), saying that he would take the voter's verdict as an invitation for serious self-examination...He said that he would make it a priority to find ways to co-operate with the opposition and implement policies for the good of nation ${ }^{59}$ (see box). This consensual rhetoric was proved by subsequent events to be hollow words and the developments of spring 2006 has offered no hope for the Taiwanese political system to become consensual.

President Chen's New Year's Day Address

31 The choice of the people [in the 2004 elections] sent a clear message: The governing party must rule with humility while the opposition parties are rational in providing oversight. Taiwan's society does not need bifurcation between the blue and green camps, nor does it need ongoing confrontation between the governing and opposition parties. The governing and opposition parties each have their own roles to play. Fair competition, co-operation rather than confrontation, checks and balances, and solidarity rather than infighting - these are now the ardent expectations of the people of Taiwan. I myself identify very strongly with the voice of the people, and fully grasp where my duties and responsibilities as President lie...I would like to hereby advocate openly that Taiwan must head towards a new era of consultation and dialogue.

During the election, there might have been a Pan-Green and Pan-Blue divide; but, with the election now behind us, there should only be "one country and a unified people" here in Taiwan... ${ }^{60}$

Taiwan President Names New Premier

Taiwan's President on Tuesday named a skilful negotiator from his party as the new premier, while pledging reconciliation between his government and the opposition alliance, as well as rival China. "We will search all possibilities for reconciliation, Chen said. We must give up partisan interests and ideological divides. ${ }^{61}$

Premier Hopes for Political Reconciliation in 2005

Hsieh called his cabinet a "reconciliation cabinet," in contrast to his predecessor's "combat cabinet". ${ }^{62}$

The New Chairman of the Democratic Progressive Party

High-ranking officials from the pan-blue and pan-green camp were stepping over each other in their effort to demonstrate their newfound respect for "political reconciliation" at a ceremony held yesterday morning at the Democratic Progressive Party's (DPP) headquarters, in which Su Tseng-chang became the new chairman of the DPP. ${ }^{63}$

10-point agreement signed

36 Marking a milestone in inter-party co-operation, President Chen Shui-bian and People First Party (PFP) Chairman James Soong held a historic meeting yesterday where they reached a consensus to acknowledge and respect the current definition of Taiwan's status, create a legal basis for cross-Strait peace, and reiterated their support for the Republic of China.

After the meeting at the Taipei Guest House yesterday morning, Chen and Soong signed a joint 10-point agreement on cross-Strait relations, national defence and ethnic reconciliation. The consensus was hailed as the beginning of dialogue and discussion between the governing and opposition camps... 

Tuesday amid pandemonium". for public office.

China Perspectives, 66 | July- August 2006

Chen's accord with Soong includes substantive and major commitments. For one, Chen openly pledged that he would not push for changing the title of the country during the remainder of his term, and that any constitutional reform would require consensus between the governing and opposition parties. ${ }^{64}$

The parliamentary gridlock, "constitutional" transfer of powers and the recall motion

The situation in the spring of 2006 became quite the reverse of the DPP's proclaimed attempts for consolidating government. After losing in the 2005 local elections the DPP was pushed back onto the defensive and as a result the prime ministerial post changed yet again. Frank Hsieh was replaced by Su Tseng-chang. The DPP tried to gain ground by abolishing the National Unification Council and National Unification Guidelines in February 2006, angering the pan blue camp, being a move that could be viewed as aimed towards an independent Taiwan. The situation in Parliament became tense, and after a series of corruption scandals that pointed to the top-most echelons of the DPP, also implicating the President's son-in-law and the President's wife, the PFP and the KMT began to consider the recall of the president. Amidst the recall discussions Chen publicly handed some constitutional powers to the Premier.

The state of gridlock in the Legislature can best be described by citing from the article published in Taipei Times on June 1st 2006, page 8: "Unsurprisingly [emphasis added], the Legislative Yuan ended its spring session in chaos, failing to pass a number of critical bills that seriously affect the livelihoods of ordinary people and the national interest. Amendments to the Statute Governing the Relations Between the People of the Taiwan Area and the Mainland Area failed for a third time after physical confrontation between the governing and opposition parties. The pan-greens stopped the Chinese Nationalist Party (KMT) and the People First Party (PFP) from putting the amendment to a vote on the legislative floor. The pan-blues, in return, blocked all of the Democratic Progressive Party's (DPP) proposals, and the legislature went into its summer recess on

The number of bills passed through the Legislative Yuan is constantly dropping. Seventy-five were passed in the last session, down from eighty-six passed during the previous session. Almost no important bills were passed during this spring session 2006, leaving many very important bills on hold ${ }^{65}$.

President Chen resolved on 31st of May 2006 that from now on all Cabinet-related matters would be in the hands of the premier. The President also said that he would respect Su's nominations for Cabinet personnel. Chen said that although as a member of the DPP he had an obligation to make a contribution to the party, he would no longer participate in DPP internal affairs, nor campaign on behalf of party members running

He has been publicly declaring what has become apparent. His loss of real power. It is however difficult to say if it is legitimate to transfer his powers into the hands of Prime Minister only or if this is just another exercise in rhetoric as the head of the KMT said: "It's absurd to cede presidential powers. It is a dereliction of duty if the President delegates the powers granted to him by the Constitution... As for powers that the President was not given constitutionally, there is nothing for him to give up or to delegate. If there are any, then they were invented by the President himself" 66 .

The former DPP Premier Frank Hsieh has probably unintentionally confirmed the notion of Chen overstepping his constitutional powers when he said that "letting 
things return to the constitutional system is a good thing. I hope Taiwanese society can gradually get back on a normal track..." ${ }^{67}$.

The final touch to the stubborn, majoritarian stance of opposing camps came into play during the last days of May 2006 when a proposal to recall President Chen Shui-bian was submitted to the legislature by pan-blue lawmakers on May 30th $2006^{68}$. The motion was signed by 72 legislators, more than the required one-quarter of the 221seat legislature. However President Chen Shui-bian survived the first-ever presidential recall vote on June 27 th, when the 119 votes for the measure fell far short of the twothirds majority needed to approve it. The recall motion had again created or, it is better to say, sustained, confrontation between the two major party alliances.

The events of spring 2006 clearly show the delegative feature of Taiwan's political system. The President feels he can make decisions about constitutional powers himself. His handing-down of presidential powers to the Prime Minister can be seen as a strong example of a President ignoring the Constitution. Either he exercised extraconstitutional powers before his move and, as is being claimed by DPP, he has now restored constitutional behaviour; or he moved his constitutional powers to the Prime Minister and is therefore behaving unconstitutionally now. Because if the President feels that he has lost the ability to exercise the powers prescribed to him by the Constitution he has the only constitutional solution-resign from office and let the vice-president do his job. That is, as a matter of fact, the reason for the existence of the vice-president's office-that he/she can step into the place of an inept President without having to go through new elections.

The majoritarian features in Taiwanese politics are being enhanced. Legislative gridlock is deepened by the inability to pass any relevant bills. The transfer of powers to the Prime Minister was aimed at strengthening executive power amid the bribery scandal touching the President and the recall motion has also strengthened the bipartisan features of Taiwan's political system, because the pan-blue and pan-green camps were set against each other during the campaign surrounding the motion process.

Taiwanese politics are working under a semi-presidential constitutional regime. It is possible to conclude that the Taiwanese political system was during Chen's first presidency moving towards the presidential system as he claimed ${ }^{69}$. However it was not because of the changing constitutional arrangement or changing institutional design of the system, but more due to the real behaviour of the key players in the political arena -President Chen himself working hard to fulfil his own predictions. After the heated election year of 2004, the players in the arena that year appeared tired of fighting without ever reaching the desired majoritarian (Caesarian) outcome. Therefore, seemingly forced by circumstances, President Chen began, with his New Year's address in 2005 , an attempt to consolidate the government's functioning by moving towards a more consensual and representative style of governing. He stepped down from the position of DPP party chairman, and thus gave more space to a consensual and representative style of governing in his own ruling (but not majority) party. Naming Frank Hsieh, one of his own rivals in the party, Prime Minister, was a prime example, the election of Su Tseng-chang as DPP party chairman was another.

On the other hand Taiwanese politics exhibits deeply anchored traits of majoritarian behaviour. Hsieh didn't succeed in including a rival party (KMT) vice-premier into his Cabinet, and the rapprochement between the DPP and KMT did not proceed. Ma Ying- 
jeou after his accession to the post of KMT chairman has begun to use tactics of "scorched earth" in the Legislative Yuan, thus blocking most DPP proposals. This majoritarian tactic, an embedded trait of Taiwanese politics which draws on deep historical and structural roots, can be seen as a means of achieving the desired consensual outcome-coalition government (on the side of the KMT). The historical roots-the authoritarian past-are already mentioned above; the structural roots of the situation consist of two main features-the SNTV voting system and from the transition to democracy rift in society. The role of the SNTV voting system can be viewed as very negative, because it puts even candidates from the same party into competition with each other ${ }^{70}$. Politics is thus getting too personalised at all levels and as such influences the players' behaviour. For example neither Lien nor Soong was present at Chen Shuibian's inauguration ceremony ${ }^{71}$. Taiwan's transition to democracy has also revealed the persistent cleavage between earlier and post-1945 immigrants and this cleavage is used in elections to sharpen the differences and polarise society. Even as the SNTV voting system is becoming obsolete, it leaves behind the legacy of deeply divided factional local politics which will take a long time to improve.

Taiwan is exhibiting only few minor signs of moving towards a more consensual or more representative government, even though such a movement would be its only possibility under the present constitutional regime for achieving democratic government functionality. The political system is unused to compromise and consensus, and views any yielding of ideals towards the pursuit of a common goal as a betrayal or weakness. The consensual approach as seen in the aftermath of the 2004 parliamentary elections will probably remain only a rhetorical figure of the past and another weapon in the majoritarian political game.

51 An easier solution from the arsenal of constitutional engineering-considering the deeply embedded majoritarian characteristics of Taiwanese politics-would be to change the design of the ROC Constitution. The recent change in voting system is claimed to solve the situation by simplifying the elections while the predicted outcome will tend to create bipartism and ease the creation of a one-party Executive government. This result is however based on one presumed outcome-the alignment of presidential and parliamentary elections. However some political commentators and even Chen himself ${ }^{72}$ claim that the result of the 2004 parliamentary elections showed the will of the electorate for reconciliation and compromise. It is therefore not unlikely that the voters in their desire for preserving the contemporary status quo on the most important Taiwan issue of division-independence versus unification with the $\mathrm{PRC}^{73}$ would split their votes, thus creating the same situation which blocks Taiwan's legislative process today.

The solution to this problem which would keep the majoritarian political system and which would eliminate the delegative features of it as a parliamentary constitutional regime coupled with a simple majority voting system in one member districts ${ }^{74}$. The simple majority voting system would in all probability produce a majority party in government and this party would be able to nominate the Prime Minister as the head of the Executive branch of government, responsible to Parliament. Only such a solution could solve the problem of legislative "gridlock" in the long term. It is also possible that the parties in the bipartisan system would have to reach for the centrist voter to win, thus easing the tension of the current divide. It is much easier to adjust the 
Constitution to fit the prevailing political culture then to try to change Taiwanese politics.

\section{NOTES}

1. This article is a revised version of a paper presented at the Second Conference of European Association of Taiwanese Studies at Ruhr University in Bochum, Germany on $1^{\text {st }}-2^{\text {nd }}$ April 2005.

2. E.g. Yu-Shan Wu, "Appointing the Prime Minister under Incongruence: Taiwan in Comparison with France and Russia", Taiwan Journal of Democracy, Vol. 1, No. 1, July 2005, pp. 103-104; Hermann Halbeisen, "Taiwan's Domestic Politics since the Presidential Elections 2000", Duisburg Working Papers on East Asian Studies, No. 53, 2003, p. 7; Robert Elgie, "Semi-Presidentialism in Europe", Oxford, Oxford University Press, 1999, p. 14; Horst Bahro et al., "Duverger's concept: Semi-presidential government revisited", European Journal of Political Research, No. 34, 1998, pp. 201-224. 3. John Fuh-sheng Hsieh, "Continuity and Change in Taiwan's Electoral Politics", in Hsieh, John Fuh-sheng and David Newman (eds.), How Asia Votes. New York, London, Chatham House, 2002, p. 33.

4. Philip Paolino, "Democratization, divided government and the 2001 Taiwanese Legislative Yuan elections", Journal of Asian and African Studies, Vol. 40, No. 1-2, February- April 2005, p. 125(23), Expanded Academic ASAP (Internet edition, November 2005).

5. Chen Shui-bian, Shiji shou hang yi zhengdang lunti wubai tian de chensi,Taipei, Yuanshen, 2001.

6. Arend Lijphart, "Trichotomy or dichotomy?", European Journal of Political Research, No. 31, 1997, pp. 127-128. Richard Moulin, Le Présidentialisme et la classification des régimes politique, Paris, Librairie générale de droit et de jurisprudence, 1978, p. 39.

7. Maurice Duverger, “A New Political System Model: Semi-Presidential Government", European Journal of Political Research, No. 8, 1980, p. 186.

8. Classifying should be based on objective criteria unbiased by the subjective opinion of authors.

9. Interpreting is based on subjective criteria and the subjective view of individual authors.

10. Robert Elgie, "Semi-Presidentialism: Concepts, Consequences and Contesting Explanations", Political Studies Review, Vol. 2, 2004, pp. 316-317.

11. Maurice Duverger, op. cit., p. 166. Duverger also addresses the apparent differences in the power of the President in governments classified as semi-presidential. He claims that the difference in the power of the President in semi-presidential systems depend on the position of the head of state in relation to any parliamentary majority. If he is that party leader, he becomes very powerful. But if he is not the head of his party, he often becomes a figurehead. If he is outside the majority, whether as an opponent or as a neutral figure, his powers then correspond to those outlined in the Constitution (Maurice Duverger, op. cit., p. 186) 
12. Giovanni Sartori, Comparative Constitutional Engineering. An Inquiry into Structures, Incentives and Outcomes, Basingstoke and London, Macmillan, 1997. Sartori himself uses the term semi-presidential system instead of Duverger's "form of government" His definition is as follows: (1) The Head of State (President) must be popularly elected for a fixed term; (2) the President shares executive power with a prime minister; (3) the President is independent from the Cabinet and legislature, although he cannot rule by himself; (4) the prime minister is formally independent from the President, but is dependent on the legislature; (5) the dual authority structure of the Executive enables flexible transfer of real executive power depending on circumstances.

13.Patrick O’Neil, “Presidential Power in Post-Communist Europe: The Hungarian Case in Comparative Perspective", Journal of Communist Studies, Vol. 9, No. 3, September 1993, p. 197.

14. Robert Elgie, "Semi-Presidentialism: Concepts, Consequences and Contesting Explanations", Political Studies Review, Vol. 2, 2004, p. 316.

15. Robert Elgie, "The Classification of Democratic Regime Types: Conceptual Ambiguity and Contestable Assumptions", European Journal of Political Research, No. 33, 1998, pp. 219-238.

16. Robert Elgie, “Semi-Presidentialism...”, pp. 316-317.

17. Robert Elgie, “The Classification of Democratic Regime Types...”, p. 235.

18. Ibid..

19. Robert Elgie, "Semi-Presidentialism...", p. 317.

20. Olivier Duhamel, “Remarques sur la notion du régime semi-présidentiel”, in Dominique Colas and Claude Emeri (eds.), Droit, institutions et systèmes politiques: Mélanges en hommage à Maurice Duverger, Paris, PUF, 1987, p. 585.

21. Thomas Sedelius, "Semi-Presidentialism in Post-Communist Countries", Paper presented at the XIII ${ }^{\text {th }}$ Nordic Political Science Association (NOPSA) Conference in Aalborg, August 15th-17th 2002, p. 16.

22. Arend Lijphart, Patterns of Democracy: Government Forms and Performance in Thirty-Six Countries, New Haven and London, Yale University Press, 1999.

23. Thomas Poguntke, "The Presidentialization of Parliamentary Democracies: A Contradiction in Terms?" Paper presented at the ECPR Workshop "The Presidentialization of Parliamentary Democracies?”, Copenhagen, April 2000, p. 13. 24. Guillermo O’Donnel, “Democracia Delegativa?”, Novos Estudios CEBRAP, No. 31, October 1991.

25. Article 2, paragraph 2 of Additional Articles to ROC Constitution (sixth revision).

26. Article 44 of ROC Constitution.

27. Ibid.

28. Op. cit., Article 133.

29. Op. cit., Article 136.

30. Shelley Rigger, "Taiwan Rides the Democracy Dragon”, The Washington Quarterly, February 23rd 2000, p. 107 (Internet edition, November $13^{\text {th }} 2005$ ).

31. Matthew Forney, Barry Hillenbrand, Don Shapiro, Jennifer Wang, "Taiwan Little Big Man.(President Chen Shui-bian)(World)", Time, May $28^{\text {th }} 2001$, Expanded Academic ASAP (Internet Edition, November $\left.13^{\text {th }} 2005\right)$.

32. Yu-Shan $\mathrm{Wu}$, op cit.

33. Hermann Halbeisen, op. cit., p. 8.

34. Ko Shu-ling, "President faces though time in the legislature - analysts", The Taipei Times, December 11th 2005, p. 3 (Internet edition). 
35. http://db.lawbank.com.tw

36. Christian Göbel, "Towards a Consolidated Democracy? Informal and Formal Institutions in Taiwan's Political Process", Paper prepared for the Conference Group on Taiwan Studies at the APSA Meeting 2001, San Francisco, August 30th - September 2nd, p. 17.

37. "Budget cuts decried by the Cabinet", The Taipei Times, January 22nd 2005, p. 3.

38. Yu-Shan Wu, op. cit.

39. Matthew Forney et al., op. cit.

40. Philip Paolino, op. cit., p. 125.

41. Pat Gao, "The Second Round", Taiwan Review, No. 3, Vol. 54, March 2004, p. 24.

42. The method of measuring the effective number of political parties comes from $M$. Laakso and R. Taagepera, "Effective Number of Parties: A Measure with Application to Western Europe", Comparative Political Studies 12 (1), 1979.

43. The more important changes are: cutting the number of MPs from 225 to 113; prolonging the terms of office from three to four years and aligning the parliamentary elections with the presidential ones; changing the SNTV voting system into the "singledistrict two votes" system; half of the national constituency going to women; 73 singlemember districts, 6 aboriginal mandates, 34 for national constituency and overseas Chinese (Hwang 2005: 14-15)

44. Christian Göbel, op. cit., p. 5.

45. Ibid., p. 6.

46. Chuang Ya-Chung, "Democracy in Action: The Making of Social Movement Webs in Taiwan", Critique of Anthropology, Vol. 24, No. 3, pp. 235-255.

47. Ming-sho Ho, "Taiwan's State and Social Movements Under the DPP Government, 2000-2004", Journal of East Asian Studies 5 (2005), pp. 401-425.

48. Hermann Halbeisen, op. cit., pp. 2-7.

49. Philip Paolino, op. cit., p. 125.

50. Hermann Halbeisen, op. cit., p. 11.

51. Hermann Halbeisen, op. cit., p. 9.

52. Bruce J. Dickson and Chien-min Chao (eds), Assessing the Lee Teng-hui Legacy in Taiwan's Politics: Democratic Consolidation and External Relations, NY, M.E. Sharpe, 2002, Introduction.

53. Jim Hwang, "Out with the Old. Taiwan is modifying its electoral system and restructuring the Legislative Yuan", Taiwan Review, Vol. 55, No. 3, March 2005, p. 14.

54. Bruce J. Dickson and Chien-min Chao (eds), op. cit.

55. Shelley Rigger, "Taiwan Rides the Democracy Dragon", The Washington Quarterly, February 23rd 2000, p. 107 (Internet Edition, November 13 $3^{\text {th }} 2005$ ).

56. Bruce J. Dickson and Chien-min Chao (eds), op. cit.

57. Matthew Forney et al., op. cit.

58. Hermann Halbeisen, op. cit., p. 4.

59. "The Democratic Way", Taiwan Review, No. 2, 2005, editorial, p. 1.

60. Presidential office news release, January $1^{\text {st }} 2005$ (Internet edition).

61. Associated Press, January 25th 2005 (Internet edition).

62. The China Post, February 12th 2005 (Internet edition).

63. Jewel Huang, The Taipei Times, February 16th 2005, p. 1 (Internet edition).

64. Caroline Hong and Huang Tai-lin, The Taipei Times, February 25th 2005, p. 1; March 6th 2005, p. 8. (Internet edition). 
65. On hold are budget bills pertaining to public infrastructure; flood-control projects; investment projects by state-owned enterprises and unfreezing around NT $\$ 200$ billion in revenue meant for the central government; review of the state public prosecutorgeneral nominee; approval of Control Yuan members and the arms-procurement plan; the draft labour insurance supervisory commission organic law; amendments to the Organic Law of the Executive Yuan that are to pave the way for government restructuring and administrative efficiency; the special budget for flood-prevention projects and many others.

66. Mo Yan-chih and Shih Hsiu-chuan, "Ma takes aim at Chen power shift", The Taipei Times, June 2nd 2006, p. 1 (Internet edition).

67. Jewel Huang, "DPP will back Cabinet, Yu says", The Taipei Times, June 2nd 2006, p. 3 (Internet edition).

68. A motion to recall the President needs the signatures of at least one-quarter of the Legislative Yuan's members-55-as well as the consent of two-thirds of all legislative members, pending final approval by half of the nation's eligible voters.

69. Chen Shui-bian, op. cit.;

70. Oscar Chung, "After the Tally. The legislative elections changed little as the opposition held onto a thin majority", Taiwan Review, Vol. 55, No. 3, March 2005, p. 8.

71. Pat Gao, op. cit., p. 23.

72. Presidential office news release, January $1^{\text {st }} 2005$ (Internet edition).

73. The opinion polls for the years 1998-2003 show the support for the status quo at around 75 to $85 \%$. Taiwan Yearbook 2004, Taiwan, GIO, 2004.

74. The proposed change of constitutional regime to reflect the parliamentary regime is not recommended for the reason that Allen Houng, convener of the Constitutional Reform Alliance, proposes-that a parliamentary system creates more political stability because government decisions are jointly made by all political parties. (Ko Shu-ling, " Constitutional reform still on the agenda, official says", The Taipei Times, June 1st 2006, p. 3 (Internet edition). But, quite the opposite, the parliamentary constitutional regime with an ideal (bipartisan) majoritarian political system can give more political stability precisely because government decisions do not have to be made jointly by all political parties. In a bipartisan system one party always has a majority and from that majority comes the head of the Executive branch of government. Great Britain is a working example of such a constitutional regime with such a political system.

\section{RÉSUMÉS}

This article considers definitions of semi-presidential systems, distinguishing prescriptive criteria (constitutional regime) and descriptive criteria (political system). Applying prescriptive criteria to the Taiwanese situation, it concludes that the Taiwanese Constitution prescribes a semi-presidential regime. The article then analyses the descriptive features of Taiwan's political system. The conclusions are enhanced by a close analysis of the situation in the aftermath of Taiwan's 2004 parliamentary elections and also from the events in the spring of 2006 (the delegation of constitutional powers and recall motion). Taiwan's political system exhibits both 
very strong majoritarian and delegative tendencies, the main reasons for the lack of functionality under the present constitutional regime. That the political system is resistant to change means, for this article, that the only possibility for democratic government functionality for Taiwan is a change of constitutional regime to one that is parliamentary ${ }^{1}$. 